\title{
Proximate Composition and Carotene Content of Three Cultivars of XanthosomaSagittifolium
}

\author{
Ihediohanma.N.C. ${ }^{1}$, OkaforD.C. ${ }^{1}$, Osuagwu. P. $\mathrm{U}^{1}$ andOnuegbu N.C. ${ }^{1}$ \\ .$^{1}$ Department of Food Science \&Technology, Federal University of Technology, Imo, Owerri, Nigeria
}

\begin{abstract}
Three cultivars of Xanthosomasagittifolium; White (XCw)-, Red (XCr)-, and Yellow (XCy) fleshed were studied for their proximate composition and carotene content. The proximate composition showed that the moisture content was highest in XCr (12.50\%) followed next by XCy (11.25\%) and 10.00\% in XCw. Fat content was $0.55 \%$ in both XCy and XCr but $0.25 \%$ in XCw. Crude protein composition was $4.21 \%$ in XCw $5.10 \%$ in XCr and $3.71 \%$ in $X C y$, showing that the red cultivar in higher in protein content. Carbohydrate content was high in all three cultivars $-X C w(79.49 \%), X C y(79.14 \%)$ and $X C r(76.75 \%) . \beta$-Carotene content of $1920 \mu \mathrm{g} / 100 \mathrm{gm} 16 \mu \mathrm{g} / 100 \mathrm{~g}$ and $8 \mu / 100 \mathrm{~g}$ was obtained from $X C Y, X C r$ and $X C w$ respectively and the vitamin A equivalent of 3200i.u, 26.67i.u and 13.33i.u from $X C y, X C r$ and $X C w$ respectively. Thus, result indicated that the colour pigments in these cultivars were mainlycarotene. Since the yellow-fleshed cultivar is rich in carotene leading to good source of vitamin A, it means that the yellow cultivar can support good nutrition as far as energy and vitamin A is concerned.
\end{abstract}

Keyword:Proximate composition, carotene content, XanthosomaSagittifolium

\section{Introduction}

Xanthosoma species commonly called new cocoyam, one of the two principal genera of aroid root crops belonging to the taxonomic family of Araceae is a native of Tropical America. First cultivated into the preColumbian times Thompson and de Wet (1983), it was later introduced into W. Africa around 1840s (Coursey, 1968). They are either eaten roasted, boiled, fried or milled to flour after drying and are popularly called cocoyam due to their resemblance to colocasia. In W. Africa, they are preferred to colocasia as they are more suitable for making 'fufu' a very popular food originally made from yam. In Ghana, the young leaves and cormels are parts of the staple diet.

A herbaceous perennial, Xanthosoma has a corm in the form of a rhizome from which cormels sprout and is propagated vegetatively. Coursey (1968) and Oguntona and Akinyele (1995) investigated and gave the approximate composition of tubers as: water $70-77 \%$, carbohydrate $17-26 \%$, protein $1.3-1.7 \%$, fibre $0.6-1.9 \%$ Ash $0.6-1.3 \%$, Fat $0.2-0.4 \%$ as well as several minerals and vitamins.

The taxonomy of Xanthosoma spp.is unclear.Cultivtated varieties have been allocated to $\underline{X}$. atrovirens, $\underline{X}$. caracu, $\underline{X}$. violaceum and $\underline{X}$. sagittifolium. In Nigeria three cultivars of $\underline{X}$. sagittifolium have been identified, i.e. white fleshed, red-fleshed and yellow-fleshed respectively. However, these three cultivars have suffered low esteem and social problems leading to discouragement in further research on them.

Nwana and Onochie (1979) identified social problems as a great obstacle to further development on cocoyam processing resulting into lack of encouragement and support. This is reflected in these varieties being poorly documented crops in which basic information about their role within West African farming system is scarce (Knipscheer and Wilson, 1981 and Onayemi and Nwigwe, 1987).

These limitations are due to lack of proper knowledge of the true values of these cultivars. The future of these cultivars to become foods of exceptional value because of their pigment characteristics and nutritional properties lies in the application of technology to diversify their use and promotion of more intensive consumption in peoples diet in tropical regions.

The objective of this study therefore was to evaluate the proximate composition and carotene content of white-, red-and yellow-fleshed Xanthosomasagittifolium.

\section{Materials and methods}

The cocoyams (Xanthosoma species) were collected from National Root Crops Research Institute, Umudike. This ensured proper history and classification of the samples to be taken. It also created an opportunity for continuous collection of the same species and varieties without mixing them up.

Three cultivars of Xanthosomasagittifolium were collected and named as follows; 
(i) White - fleshed ( $\mathrm{XCw})$

(ii) $\quad$ Red - fleshed (XCr)

(iii) Yellow - fleshed (XCy)

\section{Nature of Material}

The cocoyams used were under 7 month's cultivation. They were preferred to remain underground and collected according to need until the next farming season. The ones collected were fresh and free from injuries.

\section{Laboratory Storage}

The cocoyam corms collected were stored at a cool, dry and airy section of the laboratory and samples were gradually drawn for experiments when needed.

\section{Proximate analysis}

The moisture content, crude protein, fat content, crude fibre and total ash were determined by the methods of AOAC (1990). All analysis in this section was expressed on dry weight basis.

\section{Moisture determination}

The moisture content was determined by the moisture vacuum oven method in which $2 \mathrm{~g}$ of each samples was weighed into a dried metallic crucible of known mass and dried at a temperature of $105 \pm 1^{\circ} \mathrm{C}$, with drawn into a dessicator to cool, weighed, then reheated, cooled and reweighed and reheated. The process was repeated until a relatively constant mass was obtained. Drying was performed in duplicated and the average values recorded. The differences in masses before and after drying were recorded as moisture content.

\section{Ash determination}

The ash basic method was used. Here, $5 \mathrm{~g}$ of sample was weighed into an ashing dish which has been ignited, cooked in dessicator and weighed soon after attaining room temperature. The sample inserted into the furnance at about $550 \pm 1{ }^{\circ} \mathrm{C}$ until a light grey as resulted to a constant weight. The sample was cooled in a dessicator and weighed. The mass of residual incinerate was calculated as ash content.

\section{Crude fat determination}

A $2 \mathrm{~g}$ sample was wrapped in a filter paper and gradually lowered in the thimble which was fitted to a flask containing the solvent, petroleum ether (boiling pt. $60-80^{\circ} \mathrm{C}$ ). The round - bottomed flask, in a soxhlet extraction unit, was slowly heated for $5 \mathrm{~h}$. The filter paper with the spent (defatted) flour sample was removed from the extractor and the refluxed solvent distilled out and recovered. The filter paper containing the spent flour sample was dried at $85^{\circ} \mathrm{C}$ for $3 \mathrm{~h}$, cooled and weighed. The difference in mass was recorded as crude fat (AOCS 1990).

\section{Crude Fibre Determination}

Sample (2g) was digested with $200 \mathrm{ml} 1.25 \% \mathrm{H}_{2} \mathrm{SO}_{4}$ solution under reflux for $30 \mathrm{~min}$ boiling. The digest was allowed to cool before filtration, with butcher funnel equipped with muslin cloth secured with elastic band. The residue was washed with hot water until washing were no longer acid. The charge was then digested with $200 \mathrm{ml}$ of $1.25 \% \mathrm{NaOH}$ solution under reflux for $30 \mathrm{~min}$ boiling. The digest was cooled, filtered, washed thoroughly with hot water, the $1 \% \mathrm{HCl}$ acid, hot water and then with petroleum ether. Residue was scooped into a clean, dry and weighed porcelain dish, dried in the oven at $85^{\circ} \mathrm{C}$ to a constant mass. The dish with its content was placed inside muffle furnace at $550^{\circ} \mathrm{C}$ for $4 \mathrm{~h}$, withdrawn, cooled in dessicator and weighed. Difference in mass is reported as crude fibre.

\section{Crude protein determination}

This was determined by the semi-microkjeldahl method in which $0.2 \mathrm{~g}$ of sample was digested with $2 \mathrm{ml}$ of concentrated sulphuric acid in the presence of $0.8 \mathrm{~g}$ of catalyst mixture ( $400 \mathrm{~g}$ sodium sulphate, $16 \mathrm{~g}$ hydrated copper sulphate and $3 \mathrm{~g}$ selenium dioxide).

The digest was distilled with $15 \mathrm{ml}$ of $40 \% \mathrm{NaOH}$ into $10 \mathrm{ml}$ of $2 \%$ Boric acid. The filtrate was then titrated again $0.02 \mathrm{~N} \mathrm{HCl}$ and the average of three readings was recorded.

$$
\begin{aligned}
& \mathrm{P}=100(\mathrm{abc}) \\
& \text { d } \\
& \mathrm{a}=\text { titre value of acid }(\mathrm{HCl}) \text { used }
\end{aligned}
$$




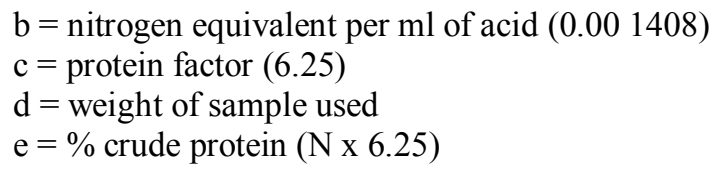

\section{Carbohydrate Determination}

This component was determined by difference. This approach was adopted on the premise that vitamins and minerals occurred in negligible quantities. The moisture, ash, fat, fiber and protein contents were summed up and subtracted from $100 \%$ to obtain the value for carbohydrate content.

\section{Carotene Content Determination Of The Cocoyam Varieties}

The carotene content was determined by the method of Stewarteet al., (1984).

\section{Sample Preparation}

Each corm was washed with tap water, peeled and cut crosswise into tussle blocks and the pieces were thoroughly mixed to ensure homogeneity.

\section{Carotene Analysis}

The carotene was extracted using wet tissues. A portion of $4 \mathrm{~g}$ was weighed from the homogenized representatives of the sample in a beaker. The sample was then transferred to a mortar and grinded with $50 \mathrm{ml}$ cold acetone. The homogenate was filtered with suction through a butchner funnel. Mortar, pestle, and residue were washed with acetone receiving washing in the funnel. The filtrate was made up to $100 \mathrm{ml}$ with acetone $(85 \%)$ and Refluxed for 30mintes with $2 \mathrm{~g}$ Barium hydroxide. The resultant filter through a separating funnel and residue was washed with acetone. A $50 \mathrm{ml}$ portion of diethyl ether was added into acetone and the mixture was allowed to stand so as to let the two phases to separate. The lower aqueous acetone Phases was discarded and the diethyl ether was washed with $20 \mathrm{ml}$ portion of distilled water to remove acetone completely and the washing were discarded. The extra was now filtered through anhydrous Sodium Sulphate $\left(\mathrm{Na}_{2} \mathrm{SO}_{4}\right)$ to dry. The optical density of standard and samples were measured using filter photo colorimeter at $420 \mathrm{~nm}$. A calibration curve was prepared for the standard and used to obtain $\beta$-carotene in the samples. The quantities obtained were converted into vitamin A equivalent using the relationship.

\section{Proximate Composition}

\section{Results And Discussion}

The results of the proximate analysis on the three cultivars of xanthosomasagittifolium were presented in table 1. All results were based on dry weight basis.

There was generally no significant difference in proximate composition between the cultivars. However, the results showed that the three cultivars of Xanthosoma studied are carbohydrate based food, generally low in protein and oil, with a bit high moisture content.

The samples showed a bit elevated moisture content between $10.00 \%$ for white-fleshed, $11.25 \%$ for yellowfleshed to $12.50 \%$ for red-fleshed. The relative elevated moisture content of cocoyam was also reported by Coursey(1968), Onwueme (1978) and (Oguntona and Akinyele, 1995), as responsible for the major drawback in the utilization potential of the products as high moisture content causes problems with food storage at ambient temperature.

The crude fat content of the samples were very low with the red and yellow fleshed having the highest amount of $0.55 \%$ each and the least amount of $0.25 \%$ in the white-fleshed. This qualified cocoyam as a low fat crop. Other lesser known low fat tubers include yam, cassava and potato.

The carbohydrate content in the red-fleshed cultivars is quite high (76.75\%), though it increased to $79.14 \%$ and $79.49 \%$ for yellow-fleshed and white-fleshed cultivars respectively. Cocoyam could be regarded as a high carbohydrate crop alongside with other tuber crops like yam and cassava with carbohydrate content of $86.0 \%$ and 93\% respectively (Oguntona and Akinyele, 1995).

Crude protein of $3.71 \%$ in the yellow-fleshed, $4.21 \%$ in the white-fleshed and $5.10 \%$ in the red-fleshed rated the crop as a better source of protein when compared with the value of $2.58 \%$ in yam reported by (Oguntona and Ainyele, 1995and Onyenuga, 1968). Considering the result, one feels that, for cocoyam to adequately supply human life their nutrient needs, they must be enhanced with foods that are high in protein quality and quantity. Such foods include leguminous crops like cowpea and other varieties of beans. 
Proximate Composition And Carotene Content Of Three Cultivars of XanthosomaSagittifolium

The cultivars have ash contents of $5.0 \%$ for white-fleshed, $4.6 \%$ for yellow-fleshed and $4.5 \%$ for redfleshed. The crude fibre content was $1.05 \%$ for white-fleshed, $0.75 \%$ for yellow-fleshed and $0.70 \%$ for red-fleshed. The ash content for food reflects its mineral element composition. Subsequently, mineral element of a food varies with the locality or soil type and virtually reflects the influence of the environments in which it was grown (Onyeikeetal., 1995).

Crude fibre is the insoluble and combustible organic residue remaining after severe acid and base hydrolysis, while dietary fibre include those plant constituent which are resistant to digestion by human gastrointestinal system (Stare and McWilliam, 1977). However, high fibre content is believed to have some adverse effect on mineral element in the body (Kesleyetal., 1978).

\section{Carotene Content of Xanthosoma species}

The carotene content of white-, red- and yellow-fleshed cultivars of xanthosoma were presented in table 2 . The table showed a low content of $8.0 \mu \mathrm{g} / 100 \mathrm{~g}$ and vitamin A equivalent of 13.33i.u in the white-fleshed (XCw), $16 \mu \mathrm{g} / 100 \mathrm{~g}$ and vitamin $\mathrm{A}$ equivalent of 26.67i.u in the red-fleshed $(\mathrm{XCr})$ and a high carotene content of $1920 \mu \mathrm{g} / 100 \mathrm{~g}$ and vitamin A equivalent of 3200i.u in the yellow-fleshed cultivars. This follows the report given by (Onwueme, 1978and Mercadante and Rodriguez-Amaya, 2007). This might suggest that the red and yellow distinctive colour in the xanthosoma cultivars is due to the presence of carotene.

Carotenoids contributed significantly to the body's total potential vitamin A intake (stare and McWilliams, 1977). A daily allowance of 2500i.u was recommended for children under 6 years as stated by Singh, (2002). The importance of vitamin A has been so highlighted in recent times by WHO and this has led to the launching of special programs to incorporate rich sources of vitamin A into diets for children and adults (FAO, 1997). The value obtained from yellow-fleshed cultivar is well adequate in meeting this allowance.

\section{Conclusion And Recommendation}

The results obtained from this work have shown that the white - red - and yellow-fleshed cultivars of Xanthosoma species contain little quantities of major nutrients like protein and oil but high in carbohydrates.Based on their proximate composition it could be referred to as high energy root crop like yam, cassava and potato and the distinctive colours in the cultivars could be due to the presence of $\beta$-carotene. This is the main provitamin A, which is a very important nutrition factor to prevent children from xerophathalmia (Nobert, 1976 Sommeret al 1983 andSommer, 1997). Thus, from the studies, it is believed that the yellow-fleshed cultivar (XCy) has great nutritional values that could be harnessed to meet nutritional needs (energy and vitamin A) and be used in the formulation of various foods.

\section{References}

[1]. Agboola, S.A (1979). An Agricultural atlas of Nigeria. Oxford University Press, England. Pp $65-68$.

[2]. Akahosi, N. (1977). A report to the Department of Food Science and Tech; University of Hawaii, Honolulu, Hawaii.

[3]. AOAC.(1990). Official Method of Analysis. $15^{\text {th }}$ edn. Association of Official Analytical chemists (AOAC). Washington, D.C

[4]. AOCS.(1990). Officialand Tentative Methods of Analysis.American Oil Chemists Society. Champaign, III.

[5]. Arene, O.B Ene, L.S.O, Odurukwe, S.O; and Eze, N.O.A (1987). Proc of the $1^{\text {st }}$ Nat. W/shop on cocoyam.Aug $16-211987$ NRCRI, Umudike Nig. Caused by Corticuimrolfsii. In: Tropical Root Crops: Research strategies for the 1980s. (Terry, E. R., Oduro, K. A and Caveness, F eds). Int'l Soc. For Trop. Roots crops, Afr. Branch Ibadan, Nig pp. $239-246$

[6]. Bell, G.H Emslier Smith, D, and Paerson, C.R (1976).Physiology and Biochemistry. $9^{\text {th }}$ edition church hill Livingstone, Edinburgh, London and New York.Pp 69.

[7]. Coursey, D.G (1968).Edible Aroids.World crops. Grampian press Ltd, Hammer shoth, London Pp. 25 - 30

[8]. Doku, E.V (1967). Root crops in Ghana.Ghana J. Sci 6(1-2): $15-36$.

[9]. Dorush, P. (1988). Cocoyams.The economics of root and tuber crops in Africa.Resource and crop mgt - program, IITA, Research Monograph No 1. Po $57-63$.

[10]. Engel, J. (1975). Underexploited tropical plants with promising economic value.adHoc panel report of the advisory committee on Technology innovation, National Academic of science, Washington D.C.

[11]. Enyi, B.A.C (1973). Inpress growth, development and yield of some tropical root crop.Proc. Third Intl. Symp Trop. Root Crops, IITA, Ibadan.

[12]. Eskin, N.A.M, Henderson, H,M and Townsend, R.J (1971). Biochemistry of foods. Academic Press, New York and London Pp. 150.

[13]. FAO. (1997). Preventing micronutrient malnutrition. A guide to Food-based approached. A manual for policy makers and programmeplanners.Food and Agricultural Organization and United Nations and Int'l Life Sciences Institute.

[14]. FAO.(1999). FAO Production years-book (1998).Food and Agricultural Organization of the United Nations. Rome. Italy.

[15]. Gooding, H.J., and Campbell, J.S (1961) Preliminary trails of West Indies xanthosoma cultivars Trop. AgricTrin, $38: 146$ - 152.

[16]. Harper, H.A., Rodwell, V.W., and Mayes, P.A (1977).Review of physiological chemistry. $16^{\text {th }}$ Edition Lange Medical Publication, LOS Atlas, California.Pp. 144.

[17]. IITA.(1982). Cocoyams.Tuber and root crop production.Manual series No 9.Int'l institute for tropical agriculture, IITA, Ibadan Nig. Pp. $193-231$ 
[18]. Ihekoronye, A.T., and Ngoddy, P.O (1985).Tropical root and tuber crops. In: Integrated food science and Technology for the tropics. Macmillan Publishers Ltd. London: Pp 270 - 281.

[19]. Kay, D.E (1973). Root crops; London, England.Tropical Products. Institute, TPI crop and product digest 2.

[20]. Kesley, J.L., Behall, K.N., and Brother, E.S (1978). Effect of fibre from fruits and vegetable on metabolic responses of human subjects Number of defecating, fecal weight, urinary, excretion of energy, and nitrogen and fat. Am..J.Chin. Nutr.. 31: 1149 - 1153.

[21]. Kato, M. Omni, S., Obata, Y., Saijo, R, and Takeo, T. (1983). A $\beta$-carotene bleaching enzyme in tea leaves, astracts of paper, Annual meeting of Agric. Chem. Soc. Japan. Sender.Pp. 227.

[22]. Kaipscheer, H.C., and Wilson, J.E.; (1981).Cocoyam farming systems in Nig. In: Tropical Root crops; Research strategies for the 1980's (Jerry E.R., Oduro, K.A and caveness F. eds). Int'1 Soc. For trop. Root Crops.Afr. Branch Ibadan, Nigeria. Pp. 247 - 254.

[23]. Margalith, P.Z (1992). The carotene pigments. In: Pigment Microbiology Chapman and Hall London.

[24]. Moy, J.H and nip, W.K (1979).Processing and storage of tomo products. In: small scale processing and storage of tropical roots crops. (Plucknett, D.L. edu, West view press Colorado. Pp. 213 - 222).

[25]. Madvewsi, J.N.C., and Onyike, R.C.I (1981). Fungal rotting of cocoyams in storage in Nigeria in: Tropical Root crops research strategies for the 1980's (Terry, E.R., Oduro, K.A; and cavenessF.eds.) Int'l Soc. For Trop. Root crops, Afr. Branch, Ibadan, Nig. Pp 235 - 238.

[26]. Mayhew, S., and Penny, A. (1988).Macmillan tropical and sub-Tropical foods.Root Vegetables. Macmillan Education Ltd. London.

[27]. Martinezpara, M.C and Tonya Isasa, M.E. (1979).The nettle as a food II.Calcium and Oxalic acid contents and their loss during boiling.Anales de Bromatolgia 31 (33/4) $332-338$.

[28]. Mercadante A. Z. and Rodriguez-Amaya B. D. (2007)Carotenoid composition and vitamin A value of some native Brazilian green leafy vegetables. International Journal of Food Science \& Technology. Volume 25, Issue 2. Pp 213-219.

[29]. Nobert, W.T (1976) Fundamentals of clinical chemistry. N.B Sauders Co., London Pp. 543.

[30]. N.R.C.R.I (1978) Processing of cocoyam. National Root crop Research institute Umudike, Umuahia N.R.C.R.T. News Letter (110:1).

[31]. N.R.C.R.I (1984).Cocoyam Research and production. National Root crops Research Institute, UmudikeUmuahia, N.R.C.R.I Research News.

[32]. Nwigwe, N.C (1986). The effect of processing methods on the oxalate content of cocoyam tuber.Msc. Thesis.University of Ife, Ile - Ife Nigeria.

[33]. Nzietchueng, S. (1985).Germs X" Update knowledge about taxonomy, botany and ethnobotany.In Abstract the $7^{\text {th }}$ symp. Of Int'l Soc. Trop Root Crops.Guadelouge, $1-6^{\text {th }}$ July 1985. Pp5.

[34]. Nwanna, I.E., and Onochie, B.E (1970).The technical and social problems of taro processing and storage in Nigeria. In: small scale processing and storage of tropical roots crops. (Plucknett, D-L. edu) West View press, Colorado. Pp. $100-109$

[35]. Nwagbo E.C, Okorji, E.C., and Ugwu, D (1987). Cocoyam and the food crop economy of Anambra state. In: Cocoyam in Nig. Proc. Of the $1^{\text {st }}$ Nat. w/shop on cocoyam NRCRI Umudike, Nig. Pp $101-112$.

[36]. Ogundana, S.K (1976). Microbial root of cocoyam (X Sagittifolium Schott) in storage in Nig. In: processing: $3^{\text {rd }}$ Int'l Biodegradation Symposium. Rhode Island, USA. Applied Science Publishers.Pp. 645 - 640.

[37]. Oguntona and Akinyele (1995).Nutrient Composition of Commonly Eaten Foods Nin Raw, Processed and Prepared.Food Foundation Publichers.Pp 6, 29, 40 - 55

[38]. Oke, O.L (1965). Nutritional studies on Nigerian food stuffs. W.Afr. 7(6) 109.

[39]. Okeke, G.C (1976). Annual report. National Root Crops Research Institute, UmudikeUmuahia, Nig.

[40]. Olorunda, A.O (1979). Storage and processing of some Nigerian root crops: In: small scale processing and storage of tropical root crop (Pluckett D.L ed). West view press, Colorado. Pp $90-99$.

[41]. Onwueme, I.C. (1978). The Tropical Tuber Crops: John Wiley, New York, U.S.A Pp. $199-225$.

[42]. Oyemuga, V.A. (1968). Nigeria's Foods and Feeding stuffs. Ibadan Varsity press, Ibadan, Nig. Pp. 9.

[43]. Onyenweaku, C.E and Eze, N.O.A (1987).Trends on production, Area and productivity of cocoyams in Nig. In: cocoyams in Nigeria $1960 / 67-1981 / 84$.

[44]. Onyeike, E.N., Olungwe, T. and Umukwe, A.A (1995).Effect of heat treamtment and defatting on the proximate composition of some Nigerian local soup thickners. J. Food Chem. 53: $173-175$.

[45]. Passan, A.C (1982) Experiments on the storage of eddoes and tannias (Colocasia and Xanthosoma spp. ) Under tropical ambient conditions Rop. Sci 24 (T) $36-39$.

[46]. Pedrona, C. (1979). Processing of food crop products, especially taro and Cassava, in western Samoa. In: small scale processing and storage of tropical root crops. (Plucknett, D. L ed) West view press, colorado. PP 258.

[47]. Purseglove, J.W (1972). Tropical crops: monocotyledons. Longman Group Ltd. London UK.

[48]. Sakai, W.S.C (1979). Aroid root crops acridity and raphides. In: Tropical Foods, chemistry and Nutrition. Vol 1, (Charalambous, G, and Inghett, G. E eds). Academic press, New York, San Francisco, London Pp. 265 - 278.

[49]. Singh, S.P (2002). Vitamins. In: A textbook of Biochemistry . $3^{\text {rd }}$ edition.CBS Publishers. New Delhi Pp. 100.

[50]. Sandal, B.R. (1970).The nature of poi carbohydrates.Proc. $2^{\text {nd }}$ Int'l Symp.Trop. Root Crops. Coll. Trop. Agr. Univ Hawaii (1) Pp. $146-$ 149.

[51]. Sommer, A. (1997).Xerophthalmia and vitamin a status.Elsevier.Volume 17 Issue 1 Pp 9-31

[52]. Sommer, A., Hussaini, G., Ignatus, T., and Susanto, D. (1983).Increased Mortality in Children with Mild Vitamin a Deficiency.The Lancet, Volume 322, Issue 8350, Pp $585-588$

[53]. Stare, F.J and McWilliams, M (1977). Living Nutrition John Willey and Sons. New York.

[54]. Stormer, R.S and Falkinham, J.O (1989).Differences in antimicrobial of mycobacteriumavium.Clin. Microbial Pp. 27,2459 - 65.

[55]. Santamaria, L. Bianechi A., and Arnaboldi, A (1988). Chemoprevention of indirect and direct chemical carcinogenesis by carotenoids as oxygen radical quenchers. Ann N.Y Acad. Sci., 534, $584-96$.

[56]. Stewarte, A., Max, H., Grimshaw, Parkinson, J. A., and Quarmby C. (1984).Clinical analysis of ecological materials.Institute of terrestrial, mark woods Research station George Oversonscombria.Pp. 296.

[57]. Tu, C.C Nip, W.K and Nakayama.T.O.M (1979).Starch and flour from taro. In: small scale processing and storage of tropical root crop (Plucknett, D.L ed). Xanthosoma (Araceae) a taxonomic and ethnobotanical conspectus. Paper prepared for the $6^{\text {th }}$ Symp. Int'l Soc. Trop. Root Crops, Luna, Peni 21 - 26 Feb 1963, 17P (Mimeo) 22 - 224. 
Proximate Composition And Carotene Content Of Three Cultivars of XanthosomaSagittifolium

Table 1: Proximate Analysis of cocoyam (Xanthosoma) species (dry weight basis).

\begin{tabular}{lllllll}
\hline Cocoyam specie & Moisture \% & Protein\% & Fat\% & Fibre\% & Ash\% & ${ }^{*}$ Carbohydrate \% \\
\hline $\mathrm{XCw}$ & $10.00 \pm 0.2$ & $4.21 \pm 0.5$ & $0.25 \pm 0.05$ & $1.05 \pm 0.3$ & $5.0 \pm 0.1$ & $79.49 \%$ \\
$\mathrm{XCy}$ & $11.25 \pm 0.2$ & $3.71 \pm 0.5$ & $0.55 \pm 0.05$ & $0.75 \pm 0.2$ & $4.6 \pm 0.1$ & $79.14 \%$ \\
$\mathrm{XCr}$ & $12.50 \pm 0.2$ & $5.10 \pm 0.6$ & $0.55 \pm 0.05$ & $0.70 \pm 0.2$ & $4.5 \pm 0.1$ & $79.75 \%$ \\
\hline
\end{tabular}

Note * By difference

Values were obtained in triplicate and the mean values recorded except for moisture content which was in duplicate and average value recorded.

Table 2: The $\beta$-carotene content in the Xanthosoma cultivars and the potential vitamin A equivalent

\begin{tabular}{lll}
\hline Cultivar & Carotene content $(\boldsymbol{\mu g} / \mathbf{1 0 0 g})$ & Vitamin A equivalent (I.U) \\
\hline $\mathrm{XCw}$ & 8.0 & 13.33 \\
$\mathrm{XCr}$ & 16.0 & 26.67 \\
$\mathrm{XCy}$ & 1920.0 & 3200 \\
\hline
\end{tabular}

Note: Values were obtained in duplicate and the average values recorded.

1 international unit of vitamin $\mathrm{A}=0.344 \mu \mathrm{g}$ of vitamin $\mathrm{A}$ acetate

international unit of vitamin $A=0.6 \mu$ g of $\beta$-carotene 